\title{
PENGARUH MODEL PEMBELAJARAN TGT (TEAMS GAMES TOURNAMENT) DENGAN MEDIA RODA PECAHAN TERHADAP HASIL BELAJAR MATERI OPERASI HITUNG PECAHAN
}

\author{
Maya Erfiyana', Rasiman², Mei Fita Asri Untari ${ }^{3}$ \\ 1,2,3 Jurusan Pendidikan Guru Sekolah Dasar \\ Universitas PGRI Semarang \\ email : erfiyanamaya@yahoo.com
}

\begin{abstract}
Abstrak
Latar belakang yang mendasari penelitian ini adalah peneliti ingin mengetahui pengaruh model pembelajaran TGT (Teams Games Tournament) dengan media roda pecahan terhadap hasil belajar materi operasi hitung pecahan pada siswa kelas IV SD Kusuma Bhakti Semarang. Penelitian ini dilakukan untuk meningkatkan hasil belajar siswa kelas IV SD Kusuma Bhakti Semarang melalui model pembelajaran TGT (Teams Games Tournament) dengan media roda pecahan. Sebelumnya hasil belajar siswa masih rendah dikarenakan dalam kegiatan belajar mengajar guru belum menggunakan model pembelajaran, guru hanya menggunakan metode ceramah dan dilanjut dengan mengerjakan soal pada buku sehingga siswa merasa cepat bosan. Subyek penelitian ini adalah siswa kelas IV-A SD Kusuma Bhakti Semarang sebagai kelas kontrol dan siswa kelas IV-B SD Kusuma Bhakti Semarang sebagai kelas eksperimen yang memiliki jumlah keseluruhan 70 siswa. Penelitian ini adalah penelitian kuantitatif menggunakan Quasi Experimental Design dengan jenis Nonequivalent Control Grup Design. Desain ini terdapat dua kelompok yang masing-masing dipilih secara rondom $(\mathrm{R})$. Kelompok pertama diberi perlakuan $(\mathrm{X})$ dan yang lain tidak diberi perlakuan. Kelompok yang diberi berlakuan disebut kelompok eksperimen dan kelompok yang tidak diberi perlakuan disebut kelompok kontrol.
\end{abstract}

Kata kunci: Model Teams Games Tournament, Hasil Belajar Matematika

\begin{abstract}
The background that underlies this research was that the researcher wants to find out the effect of the TGT learning model with fractional wheel media on the learning outcomes of fraction counting operations in fourth grade students at SD Kusuma Bhakti Semarang. This research was conducted to improve the learning outcomes of fourth grade students of SD Kusuma Bhakti Semarang through the TGT learning model (Teams Games Tournament) with broken wheel media. Previously student learning outcomes were still low because in teaching and learning activities the teacher had not used the learning model, the teacher only used the lecture method and continued by working on the questions on the book so that students felt bored quickly. The subjects of this study were grade IV-A students at SD Kusuma Bhakti Semarang as a control class and grade IV-B students at SD Kusuma Bhakti Semarang as an experimental class with a total of 70 students. This research was a quantitative study using Quasi Experimental Design with the type of Nonequivalent Control Design Group. This design has two groups, each of which chosen by rondom $(R)$. The first group was given treatment $(X)$ and the other was not treated. The group given the action is called the experimental group and the group that was not treated was called the control group.
\end{abstract}

Keywords: Model Teams Games Tournament, Mathematics Learning Outcomes 


\section{Pendahuluan}

Pendidikan pada saat ini merupakan aspek yang penting bagi manusia, sehingga banyak masyarakat sekarang ini rela mengeluarkan uang banyak untuk menempuh pendidikan. Pentingnya pendidikan bagi manusia hingga diatur dan dicantumkan dalam Undang-Undang Nomor 20 Tahun 2003 pasal 1 yang menjelaskan bahwa pendidikan adalah usaha sadar dan terencana untuk mewujudkan suasana belajar dan proses pembelajaran agar peserta didik secara aktif mengembangkan potensi dirinya untuk memiliki kekuatan spiritual keagamaan, pengendalian diri, kepribadian, kecerdasan, akhlak mulia, serta keterampilan yaang diperlukan dirinya, masyarakat, bangsa dan negara.

Pendidikan juga merupakan suatu aspek kehidupan yang sangat mendasar bagi pembangunan bangsa dalam suatu negara. Dalam penyelenggaraan pendidikan di sekolah sebagai lembaga pendidikan formal melibatkan guru sebagai pendidik dan siswa sebagai peserta didik yang diwujudkan dalam suatu proses pembelajaran. Dalam ruang lingkup penyelenggaraan pendidikan ini guru dengan sadar merencanakan kegiatan pembelajaran secara sistematis dan berpedoman pada seperangkat aturan yang dikemas dalam bentuk kurikulum.

Kurikulum secara berkelanjutan disempurnakan untuk meningkatkan mutu pendidikan. Namun, masalah yang dihadapi dalam dunia pendidikan saat ini adalah berbagai kelemahan dalm proses pembelajaran di dalam kelas. Berdasarkan kenyataan di lapangan, proses pembelajaran di kelas kurang meningkatkan keaktifan dan kekreaktifan peserta didik di kelas. Proses pembelajaran di kelas cenderung lebih mementingkan pada penghafalan konsep bukan pemahaman. Dengan demikian suasana menjadi tidak kondusif yang menyebabkan siswa menjadi pasif.

Dalam proses belajar mengajar ada empat komponen penting yang berpengaruh bagi keberhasilan belajar siswa, yaitu bahan belajar, suasana belajar, media dan sumber belajar, serta guru sebagai subyek pembelajaran. Komponen-komponen tersebut sangat penting dalam proses belajar, sehingga melemahnya satu atau lebih komponen dapat menghambat tercapainya tujuan belajar yang optimal. Media sebagai salah satu komponen dalam kegiatan belajar mengajar dan sumber belajar yang digunakan dalam pembelajaran dipilih atas dasar tujuan dan bahan pelajaran yang telah ditetapkan, oleh karena itu guru sebagai subyek pembelajaran harus dapat memilih media dan sumber belajar yang tepat, sehingga bahan pelajaran yang disampaikan dapat diterima siswa dengan baik ( Sundayana, 2013:25).

Matematika merupakan suatu disiplin ilmu yang mempunyai kekhususan dibanding dengan disiplin ilmu lainnya yang harus memperhatikan hakikat matematika dan kemampuan siswa dalam belajar. Tanpa memperhatikan faktor tersebut tujuan kegiatan belajar tidak akan berhasil. Seorang dikatakan belajar bila dapat diasumsikan dalam diri orang itu menjadi suatu proses kegiatan yang mengakibatkan suatu perubahan tingkah laku. Perubahan tingkah laku itu dapat diamati dan berlangsung dalam waktu yang relatif lama disertai usaha yang dilakukan sehingga orang tersebut dari yang tidak mampu mengerjakan sesuatu menjadi mampu mengerjakannya (Hudojo, 1988).

Matematika merupakan pelajaran yang sukar dipahami. Hal ini salah satunya disebabkan kurangnya siswa memahami mata pelajaran matematika. Dampaknya motivasi untuk belajar matematika menurun yang berpengaruh juga terhadap prestasi belajar siswa. Matematika berkenaan dengan ide-ide dan hubungannya diatur dengan logika, sehingga sebagian besar materi matematika bersifat abstrak. Hal tersebut membuat siswa merasa kesulitan dalam mempelajarinya (Rostina, 2013: 2).

Upaya peningkatan hasil belajar peserta didik tidak terlepas dari beberapa faktor yang mempengaruhinya. Dalam hal ini diperlukan guru yang kreatif untuk membuat pembelajaran menjadi lebih menarik dan disukai oleh peserta didik. Suasana kelas juga perlu dibangun sedemikian rupa dengan melaksanakan pembelajaran menggunakan media dan model pembelajaran yang tepat agar peserta didik dapat memperoleh kesempatan untuk berinteraksi satu sama lain sehingga pada gilirannya diperoleh hasil belajar yang optimal. 
Melalui hasil wawancara dengan guru kelas IV ditemukan bahwa data hasil belajar peserta didik pada mata pelajaran Matematika, khususnya materi Operasi Hitung Bilangan Pecahan di kelas IV SD Kusuma Bhakti Semarang, pada ulangan harian semester 1 tahun ajaran $2018 / 2019$ dari 35 siswa ditiap kelas hanya $40 \%$ siswa yang mendapat nilai $\geq 60$. Nilai ini belum mencapai Kriteria Ketuntasan Minimal (KKM) yang ditetapkan oleh sekolah yaitu 60. (Sumber : Data Nilai Siswa Kelas IV Semester I SD Kusuma Bhakti Tahun Ajaran 2018/2019).

Berdasarkan hasil observasi di SD Kusuma Bhakti Semarang, keberhasilan proses belajar diukur melalui prestasi belajar, masih ada beberapa peserta didik yang tidak mampu mencapai nilai sesuai dengan Kriteria Ketuntasan Minimal (KKM) pada materi operasi bilangan pecahan, hal ini dapat diketahui melalui hasil ulangan harian siswa yang belum mencapai KKM. Selain itu, hal yang menjadi penyebab rendahnya hasil belajar peserta didik adalah pembelajaran yang monoton dengan tidak menerapkan model dan media pembelajaran sehingga peserta didik cenderung merasa bosan dan tidak tertarik pada pembelajaran, dimana peserta didik menjadi kurang aktif dalam proses pembelajaran.

Penerapan model pembelajaran kooperatif tipe TGT (Teams Games Tournament) merupakan kegiatan pembelajaran yang menciptakan suasana belajar yang tidak membosankan dimana peserta didik merasa ambil bagian dan berperan aktif dalam proses pembelajaran. Model pembelajaran kooperatif tipe TGT ini, pada hakekatnya dirancang untuk memberikan kesempatan kepada peserta didik agar dapat belajar melalui kegiatan bermain, berlomba dan bekerjasama dalam tim. Keberhasilan dari penerapan model pembelajaran kooperatif tipe TGT tergantung pada peran dan kesiapan guru di dalamnya. Peran guru tersebut sangat tergantung dari kegiatan pembelajaran yang digunakan, juga materi yang diajarkan.

Pengertian model pembelajaran TGT menurut Rusman (2012:224) adalah salah satu tipe model pembelajaran kooperatif yang menempatkan siswa dalam kelompok-kelompok belajar yang beranggotakan 5-6 siswa yang memiliki kemampuan, jenis kelamin, dan suku atau ras yang berbeda. Sedangkan Saco (dalam Rusman, 2012:224) mengatakan bahwa dalam TGT siswa memainkan permainan dengan anggota-anggota tim (kelompok) lain untuk memperoleh skor bagi tim mereka masing-masing. Pembelajaran kooperatif tipe TGT (Slavin, 2007:166-167) terdiri dari lima langkah, yaitu: penyajian kelas (class presentation), belajar dalam kelompok (teams), permainan (games), pertandingan (tournament), dan penghargaan kelompok (team reognition). Dalam model pembelajaran TGT, siswa dibagi dalam beberapa kelompok kecil yang anggota kelompoknya dipilih secara heterogen. Kelompok-kelompok ini akan belajar secara bersama-sama (teams) dan akan melakukan permainan (games) untuk menyelesaikan permasalahan, sedangkan tournament dilaksanakan setelah pembelajaran selesai. Model pembelajaran TGT menerapkan sistem pemberian skor, dengan tujuan agar siswa semangat belajar dan melatih siswa untuk berkompetisi dengan jujur. Selanjutnya kelompok yang mendapat skor paling banyak ditentukan sebagai pemenang dan mendapat hadiah dari guru. Model pembelajaran ini memiliki ciri -ciri: 1) siswa bekerja dalam kelompokkelompok kecil; 2) games tournament; dan 3) penghargaan kelompok (Rusman, 2012:225).

Dengan menerapkan model pembelajaran TGT di kelas diharapkan dapat menghilangkan anggapan siswa tentang matematika adalah pelajaran yang membosankan. Karena dalam model TGT siswa belajar secara berkelompok, terdapat permainan yang berupa tournament, dan penghargaan untuk kelompok yang memperoleh skor terbanyak. Menurut Sudha (2016) dengan diterapkanya model pembelajaran kooperatif tipe Teams Games Tournamet (TGT) dapat membuat siswa untuk saling berkolaboratif dan memotivasi satu sama lain dengan kemampuan yang berbeda-beda, sehingga siswa dapat lebih tertarik, tidak mudah menyerah dan selalu aktif dalam mengikuti dan menyelesaikan tugasnya dalam proses pembelajaran. Selain itu, semua siswa terlibat secara aktif dalam pembelajaran, serta dapat menumbuhkan rasa kebersamaan dan saling menghargai sesama anggota kelompok (Shoimin, 2014:208). Model pembelajaran ini sangat sesuai jika diterapkan pada kelas yang memiliki kemampuan heterogen karena siswa yang kemampuannya kurang akan dibantu oleh siswa yang memiliki kemampuan baik pada saat kerja kelompok ( Sudimayasa, 2015). Sehingga siswa akan senang belajar matematika dan siswa lebih mudah memahami materi yang 
disampaikan guru. Jadi penerapan model TGT dalam pembelajaran matematika di kelas memiliki dampak positif bagi hasil belajar siswa.

Penelitian ini dilakukan dengan model pembelajaran TGT (Teams Games Tournament) serta berbantu media roda pecahan yaitu suatu media pembelajaran matematika berbentuk lingkaran yang menempel pada papan persegi panjang digunakan sebagai alat bantu untuk menyampaikan materi pecahan. Penggunaan media roda pecahan bertujuan untuk mempermudah dalam menyampaikan materi pecahan dengan indikator menyelesaikan masalah atau soal cerita yang berkaitan dengan pecahan.

Model pembelajaran TGT (Teams Games Tournament) sudah terbukti efektif dalam meningkatkan hasil belajar peserta didik. Hal ini dapat dilihat dari penelitian yang telah dilakukan oleh Sigit Fian Rianto dengan judul Pengaruh Model Pembelajaran TGT Berbantu Media Pupepi Terhadap Hasil Belajar Matematika Materi Pecahan Kelas III SDN Manjang 01 Pati. Berdasarkan hasil uji-t diperoleh ${ }^{t_{\text {hitung }}}>t_{\text {tabel }}$ atau 6,561 $>1,72$. Maka ${ }^{H_{0}}$ ditolak artinya model pembelajaran TGT (Teams Games Tournament) berpengaruh terhadap hasil belajar materi pecahan pada siswa kelas III SDN Manjang 01 Pati.

Penelitian serupa juga pernah dilakukan oleh Sri Rochanah dengan judul Pengaruh Model TGT (Teams Games Tournament) Berbantu Media Flash Card Terhadap Hasil Belajar IPS Siswa Kelas III SDN Kalibalik 03 Kecamatan Banyuputih Kabupaten Batang. Berdasarkan

analisis uji-t didapat $t_{\text {hitung }}(2,460)>t_{\text {tabel }}$ (2,201). Maka dapat disimpulkan model pembelajran TGT (Teams Games Tournament) berpengaruh terhadap hasil belajar siswa pada mata pelajaran IPS di Kelas III SDN Kalibalik 03 Kecamatan Banyuputih Kabupaten Batang.

Dari uraian permasalahan diatas, maka penulis tertarik melakukan Penelitian dengan judul "Pengaruh Model Pembelajaran TGT Dengan Media Roda Pecahan Terhadap Hasil Belajar Materi Operasi Hitung Pecahan Pada Siswa Kelas IV SD Kusuma Bhakti Semarang".

\section{Metode}

Desain yang digunakan dalam penelitian ini yaitu Quasi Experimental Design dengan bentuk Nonequivalent Group Pretest Posttest. Jakni (2016:73) menyatakan bahwa dalam quasi eksperimental design ini memiliki kelompok kontrol,tetapi tidak dapat berfungsi sepenuhnya untuk mengontrol variabel-variabel luar yang mempengaruhi pelaksanaan eksperimen.

Menurut Sugiyono (2017:112) bentuk Nonequivalent Group Pretest Posttest, hanya pada desain ini kelompok eksperimen maupun kelompok kontrol tidak dipilih secara random . Dalam penelitian kelompok eksperimen akan diberikan treatmen atau perlakuan, yaitu dengan menggunakan model TGT (Teams Games Tournament) dengan media roda pecahan, sedangkan kelompok kontrol merupakan kelompok yang tidak diberikan perlakuan. Pengaruh perlakuan adalah $\left(\mathrm{O}_{2}-\mathrm{O}_{1}\right)-\left(\mathrm{O}_{4}-\mathrm{O}_{3}\right)$ (Sugiyono, 2017:116). Bentuk Nonequivalent Group Pretest Posttest adalah sebagai berikut :

\begin{tabular}{|lll|}
\hline$O_{1}$ & $\mathrm{X}$ & $O_{2}$ \\
& & \\
$O_{3}$ & & $O_{4}$ \\
\hline
\end{tabular}

Gambar 1. Desain Penelitian

Penelitian ini dilaksanakan di SD Kusuma Bhakti Semarang pada tanggal 8-15 April 2019 tahun ajaran 2018/2019. Populasi dalam penelitian ini adalah seluruh peserta didik kelas IV-A dan IV-B SD Kusuma Bhakti Semarangdengan jumlah masing-masing kelas terdiri dari 35 siswa. kelas IV-A sebagai kelas kontrol yang artinya tidak mendapat perlakuan sedangkan 
untuk kelas IV-B adalah kelas eksperimen yang artinya mendapat perlakuan yaitu dengan menggunakan model pembelajaran TGT (Teams Games Tournament) dan media rode pecahan.

Penelitian diawali dengan melakukan observasi proses pembelajaran dikelas dan nilai Ulangan Harian peserta didik dalam materi operasi hitung pecahan untuk memperoleh data awal permasalahan peserta didik. Berdasarkan permasalahan yang ada, sebagai upaya untuk meningkatkan hasil belajar peserta didik dalam mata pelajaran matematika materi operasi hitung pecahan (penjumlahan dan pengurangan), maka peneliti menerapkan model pembelajaran TGT (Teams games Tournament) dengan berbantu media roda pecahan. Kemudian peneliti juga melakukan wawancara dengan guru kelas IV SD Kusuma Bhakti Semarang berkaitan dengan penggunaan model dan media pembelajaran serta kegiatan belajar mengajar dikelas yang dilakukan oleh guru. Setelah melakukan wawancara peneliti melanjutkan dengan membuat instrumen penelitian yaitu berupa RPP, Silabus, Soal yang berkaitan dengan materi operasi hitung pecahan (penjumlahan dan pengurangan), serta kisikisi soal.

Teknik pengumpulan data dalam penelitian ini adalah wawancara, observasi, dokumentasi, dan tes. Wawancara dilakukan untuk mengetahui kondisi awal peserta didik serta permasalahan yang ada di sekolah. Observasi dilakukan untuk mengamati proses kegiatan belajar di kelas untuk mengetahui segala aktivitas guru dan siswa dikelas. Dokumentasi yang digunakan yaitu daftar nama dan nilai siswa, serta dokumentasi selama proses kegiatan pembelajaran selama penelitian berlangsung. Dalam penelitian ini menggunakan metode tes, tes digunakan untuk mendapatkan data hasil belajar siswa materi Operasi Hitung Pecahan. Data yang dimaksud adalah hasil belajar kognitif siswa kelas IV SD Kusuma Bhakti Semarang. Tes dilakukan sebelum proses belajar mengajar dilaksanakan (pretest) dan sesudah proses belajar mengajar(posttest). Hasil ini juga digunkan untuk mengetahui pengaruh model pembelajaran TGT (Teams Games Tournament) dan media Roda Pecahan.

Teknik analisis data yang digunakan terdiri dari Uji Normalitas, Uji Homogenitas, dan Uj Hipotesis (Uji-T). Uji Normalitas dilakukan untuk mengetahui bahwa sampel berasal dari populasi berdistribusi normal. Uji Homogenitas digunakan untuk menguji kesamaan (homogen) dari kedua varians. Uji homogenitas menggunkan uji $\mathrm{F}$, dengan kriteria Jika $F_{\text {hitung }}<F_{\text {tabel }}$ varians kedua kelompok sama dan Jika $F_{\text {hitung }} \geq F_{\text {tabel }}$ varians kedua kelompok tidak sama, untuk mengetahui apakah kelas tersebut homogen dengan kriteria Ha ditolak dan Ho diterima. Yang terakhir yaitu Uji Hipotesis yang digunakan untuk menjawab hipotesis penelitian dengan menggunakan rumus Uji T dengan kriteria $t_{\text {hitung }}<t_{\text {tabel }}$.

\section{Hasil Dan Pembahasan}

Berdasarkan penelitian yang telah dilakukan, data dalam penelitian ini terdiri dari dua macam yaitu data awal dan data akhir. Data awal diambil dari nilai pretest kontrol maupun kelas eksperimen se belum proses pelaksanaan pembelajaran berlangsung, sedangkan data akhir diambil dari nilai posttest kelas kontrol yang tidak mendapatkan perlakuan dan kelas ekperimen yang mendapatkan perlakuan.

Hasil pengolahan data tersebut digunakan untuk membuktikan bahwa model Teams Games Tournament (TGT) dengan bantuan media roda pecahan berpengaruh terhadap hasil belajar peserta didik kelas IV materi operasi hitung pecahan (penjumlahan dan pengurangan).

\section{Perhitungan skor prettest}

Setelah melakukan tes awal (pre-test) nilai siswa kelas kontrol dan kelas eksperimen dapat dikatakan masih banyak yang belum mencapai Kriteria Ketuntasan Minimal yang sudah ditentukan sekolah yaitu 60. Dari hasil pelaksanaan pre-test masih banyak siswa yang nilainya dibawah 60. Data nilai pre-test kelas kontrol yang berjumlah 35 siswa menunjukkan jumlah sebesar 1280. Rata-rata pre-test menunjukkan 36,57 . Berdasarkan data nilai di atas, terdapat 
31 siswa belum mencapai KKM dan 4 siswa sudah mencapai KKM yaitu 60. Hasil penghitungan ketuntasan belajar peserta didik, dari 35 siswa hanya 4 siswa yang tuntas secara individu, sehingga ketuntasan klasikalnya sebesar $11,43 \%$ yang artinya belum mencapai kriteria ketuntasan klasikal sekurang-kurangnya $80 \%$.. Sedangkan untuk kelas eksperimen Data nilai pre-test kelas eksperimen yang berjumlah 35 siswa menunjukkan jumlah sebesar 1545. Rata-rata pre-test menunjukkan 44,14. Berdasarkan data nilai di atas, terdapat 29 siswa belum mencapai KKM dan 6 siswa sudah mencapai KKM yaitu 60. Hasil penghitungan ketuntasan belajar peserta didik, dari 35 siswa hanya 6 siswa yang tuntas secara individu, sehingga ketuntasan klasikalnya sebesar $17,14 \%$ yang artinya belum mencapai kriteria ketuntasan klasikal sekurang-kurangnya $80 \%$.

\section{Perhitungan skor posttest}

Proses kegiatan penelitian selanjutnya adalah menganalisis data akhir yaitu data nilai post-test kelas kontrol dan post-test kelas eksperimen. Data nilai pre-test kelas kontrol yang berjumlah 35 siswa menunjukkan jumlah sebesar 2245. Rata-rata pre-test menunjukkan 64,14. Berdasarkan data nilai di atas, terdapat 12 siswa belum mencapai KKM dan 23 siswa sudah mencapai KKM yaitu 60. Hasil penghitungan ketuntasan belajar peserta didik, dari 35 siswa ada 23 siswa yang tuntas secara individu, sehingga ketuntasan klasikalnya sebesar 65,71\% yang artinya belum mencapai kriteria ketuntasan klasikal sekurang-kurangnya $80 \%$. Sedangkan Data nilai post-test kelas eksperimen yang berjumlah 35 siswa menunjukkan jumlah sebesar 2660. Rata-rata post-test menunjukkan 76,00. Berdasarkan data nilai di atas, terdapat 3 siswa belum mencapai KKM dan 32 siswa sudah mencapai KKM yaitu 60. Hasil penghitungan ketuntasan belajar peserta didik, dari 35 siswa hanya ada 3siswa yang tidak tuntas, sehingga ketuntasan klasikalnya sebesar $91,43 \%$ yang artinya sudah mencapai kriteria ketuntasan klasikal sekurang-kurangnya $80 \%$.

Dengan penggunaan model TGT (Teams Games Tournament) terlihat perbedaan nilai akhir pada kelas kontrol dan kelas eksperimen. Rata-rata hasil belajar pada kelas eksperimen lebih tinggi dibandingkan rata-rata hasil belajar kelas kontrol. Rata-rata nilai yang diperoleh kelas kontrol sebesar 64,14 sedangkan rata-rata nilai kelas eksperimen sebesar 76,00 dapat dilihat dari selisih keduanya yaitu sebesar 11,86. Perbedaan tersebut disajikan dalam gambar diagram berikut.

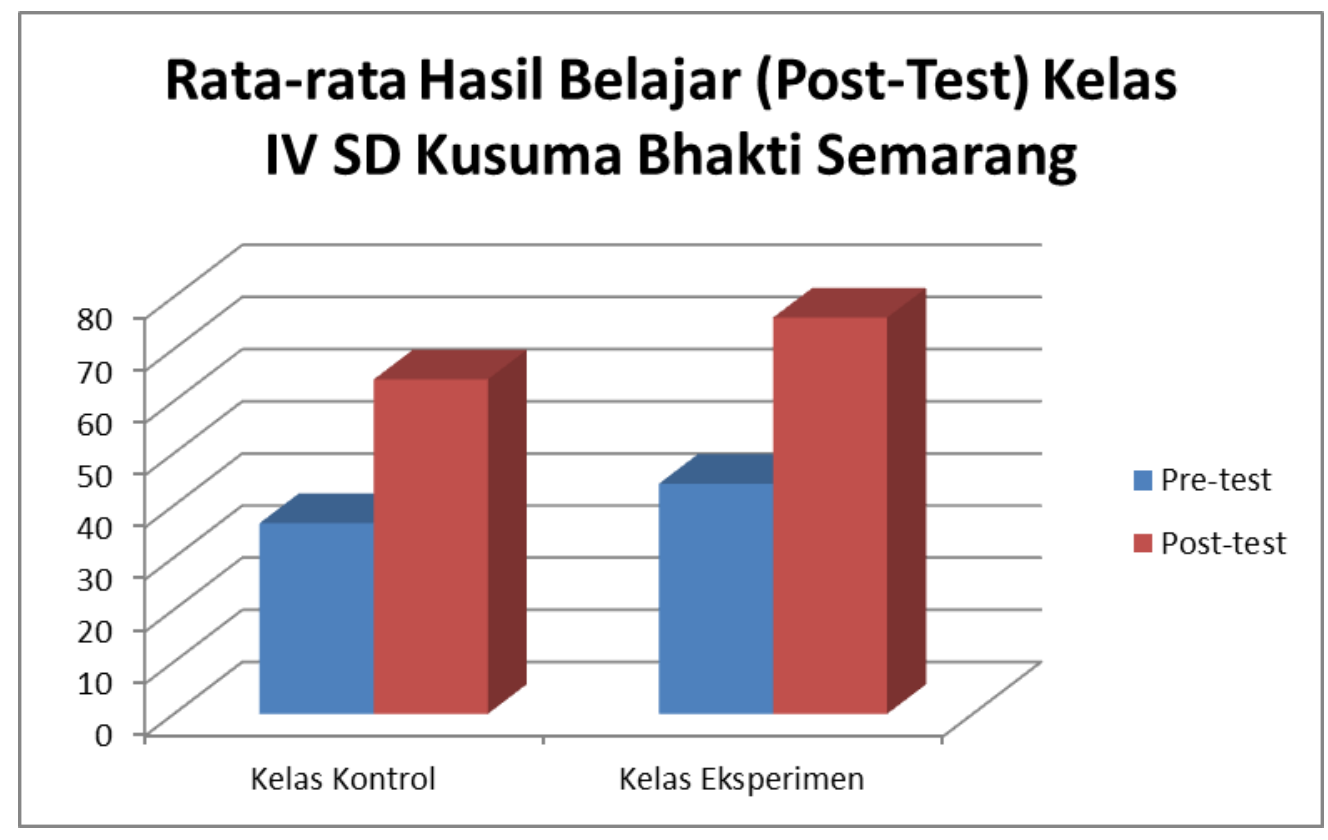

Gambar 2. Diagram Hasil Belajar Siswa Kelas IV 
Berdasarkan hasil penelitian terdapat peningkatan yang signifikan pada kelas eksperimen dibandingkan dengan kelas kontrol. Data yang telah diolah dengan uji normalitas akhir kelas kontrol diperoleh $L_{\text {hitung }}=0,0944$ dan $L_{\text {tabel }}=0,1498$ yang diperoleh dari daftar tabel Liliefors dengan $n=35$ dan taraf signifikan (a) $5 \%$, maka $L_{\text {hitung }}<L_{\text {tabel }}$ yaitu $0,0944<0,1498$, dengan demikian $\mathrm{H}_{0}$ diterima. Berdasarkan hasil penghitungan tersebut dapat disimpulkan bahwa sampel dari kelas kontrol berdistribusi normal, sedangkan pada uji normalitas akhir kelas kontrol diperoleh $L_{\text {hitung }}=0,1022$ dan $L_{\text {tabel }}=0,1498$ yang diperoleh dari daftar tabel Liliefors dengan $n=35$ dan taraf signifikan ( $\alpha$ ) $5 \%$, maka $L_{\text {hitung }}<L_{\text {tabel }}$ yaitu 0,1022 $<0,1498$, dengan demikian $\mathrm{H}_{0}$ diterima. Berdasarkan hasil penghitungan tersebut dapat disimpulkan bahwa sampel dari kelas kontrol berdistribusi normal. Untuk mengetahui kedua kelompok sama atau homogen, maka penghitungan uji homogenitas data akhir kelas kontrol dan kelas eksperimen diperoleh varians kelas kontrol $=15,266$ dan varians kelas eksperimen $=13,105$, sehingga diperoleh $\mathrm{F}_{\text {hitung }}=1,3569$. Berdasarkan daftar tabel dengan taraf signifikan $5 \%$ dengan dk pembilang $=34$ dan dk penyebut $=34$, diperoleh $F_{\text {tabel }}=1,80$. Dari penghitungan tersebut maka $F_{\text {hitung }}<F_{\text {tabel }}$ yaitu 1,3569 $<1,80$, maka kesimpulannya yaitu kedua kelompok tersebut berasal dari populasi yang sama atau homogen. Kemudian untuk mengetahui apakah model TGT (Teams Games Tournament) dengan media roda pecahan berpengaruh terhadap hasil belajar matematika operasi hitung pecahan kelas IV SD Kusuma Bhakti Semarang, maka akan dilakukan Uji-T. Hasil penghitungan persyaratan data menunjukkan bahwa sampel hasil belajar berdistribusi normal. Selanjutnya diketahui bahwa rata-rata hasil belajar kelas eksperimen lebih tinggi dibandingkan dengan kelas kontrol. Untuk menguji perbedaan hasil belajar kedua kelompok tersebut, maka dilakukan dengan penghitungan uji t (uji banding dua sampel). Hipotesis yang akan diuji adalah :

$H_{0}=t_{\text {hitung }}<t_{\text {tabel }}$ tidak ada pengaruh hasil belajar antara pembelajaran yang menggunakan model pembelajaran TGT (Teams Games Tournament) berbantu media roda pecahan dengan model pembelajaran konvensional pada mata pelajaran matematika materi pecahan.

$H_{a}=t_{\text {hitung }}>t_{\text {tabel }}$ ada pengaruh hasil belajar antara pembelajaran yang menggunakan model pembelajaran TGT (Teams Games Tournament) berbantu media roda pecahan dengan model pembelajaran konvensional pada mata pelajaran matematika materi pecahan.

Berdasarkan penghitungan uji t pada data akhir kedua sampel, diperoleh $t_{\text {hitung }}=$ 3,537295. Dari daftar tabel, dengan $\mathrm{dk}=\left\{\left(\mathrm{n}_{1}+\mathrm{n}_{2}\right)-2\right\}=68$ dengan taraf signifikan $5 \%$, maka diperoleh $t_{\text {tabel }}=1,66757$, sehingga hasil pengitungan uji $t$ diperoleh $t_{\text {hitung }}>t_{\text {tabel }}$ yaitu 3,537295 > 1,66757. Berdasarkan hasil tersebut, maka $H_{0}$ ditolak dan $H_{a}$ diterima, artinya model TGT (Teams Games Tournamen)t dengan bantuan media roda pecahan berpengaruh terhadap hasil belajar matematika materi pecahan siswa kelas IV SD Kusuma Bahkti Semarang.

Selain itu dapat dibuktikan dengan perhitungan ketuntasan belajar dengan menggunakan uji t dapat disimpulkan nilai tes siswa setelah mengggunakan model pembelajaran TGT (Teams Games Tournament) berbantu media roda pecahan 32 siswa dinyatakan tuntas dengan nilai lebih dari 60 , sehingga ketuntasan klasikalnya sebesar $91,43 \%$ yang artinya sudah mencapai kriteria ketuntasan klasikal sekurang-kurangnya $80 \%$. Dengan demikian model TGT (Teams Games Tournament) dengan bantuan media roda pecahan berpengaruh terhadap hasil belajar matematika materi operasi hitung pecahan (penjumlahan dan pengurangan) siswa kelas IV SD Kusuma Bhakti Semarang.

Berdasarkan hasil penelitian yang telah dilakukan oleh peneliti dapat diketahui bahwa pembelajaran dengan menggunakan model TGT (Teams Games Tournament) berbantu media roda pecahan lebih berpengaruh dalam meningkatkan hasil belajar siswa. Hasil penelitian menunjukkan bahwa model pembelajaran TGT (Teams Games Tournament) berbantu media roda pecahan juga membantu guru dalam mengelola kelas selama pembelajaran berlangsung. Hal ini dikarenakan siswa lebih tertarik, merasa senang serta dapat mendukung dan membantu penyerapan siswa aktif selama proses pembelajaran berlangsung. Hasil belajar masing-masing peserta didik ditunjang oleh beberapa faktor salah satunya karena kerjasama dan interaksi yang terjadi dalam kelompok sehingga peserta didik dapat lebih mudah memahami soal yang diberikan sehingga hasil belajar siswa mengalami peningkatan. 


\section{Simpulan dan Saran}

Berdasarkan uraian dan analisis data dapat disimpulkan bahwa terdapat pengaruh yang signifikan model TGT (Teams Games Tournament) berbantu media roda pecahan terhadap hasil belajar Matematika Kelas IV SD Kusuma Bhakti Semarang Tahun Pelajaran 2018/2019. Hal ini dapat dilihat dari rata-rata hasil belajar kelas eksperimen yang mengalami peningkatan lebih banyak dari kelas kontrol, dan itu dibuktikan dari hasil rata-rata kelas eksperimen yang sebelum perlakuan 44,14 dan setelah perlakuan meningkat menjadi 76,00 . Begitupun dengan kelas kontrol yang sebelum perlakuan hasil rata-ratanya sebesar 36,57 dan setelah perlakuan hasil rata-rata meningkat menjadi 64,14.

Jika dilihat dari analisis uji hipotesis untuk menguji ada atau tidaknya pengaruh model TGT (Teams Games Tournament) berbantu media roda pecahan terhadap hasil belajar Matematika Kelas IV diperoleh $t_{\text {hitung }}>t_{\text {tabel }}$ yaitu 3,537295 > 1,66757 maka $\mathrm{H}_{0}$ ditolak sehingga menunjukkan bahwa TGT (Teams Games Tournament) berbantu media roda pecahan berpengaruh terhadap hasil belajar Matematika materi operasi hitung pecahan Kelas IV SD Kusuma Bhakti Semarang Tahun Pelajaran 2018/2019. Kemudian saran dalam penelitian ini adalah :

Model pembelajaran TGT (Teams Games Tournament) dengan media roda pecahan dapat meningkatkan hasil belajar peserta didik, oleh karena itu guru perlu mencoba menerapkan model TGT (Teams Games Tournament) dengan media roda pecahan agar anak lebih bersemangat dan antusisas dalam mengikuti pembelajaran pada mata pelajaran matematika khususnya. Dalam mengunakan model pembelajaran model TGT (Teams games Tournament) berbantu media roda pecahan, pembelajaran harus dikemas dengan menyenangkan agar siswa nyaman dan termotivasi dalam belajar didalam kelas.

\section{Daftar Rujukan}

Arifin, Zainal. 2010. "Evaluasi Pembelajaran”. Bandung: PT Remaja Rosdakarya.

Arikunto, Suharsimi. 2016. Dasar-dasar Evaluasi Pendidikan. Jakarta: Bumi Aksara.

Arsyad, Azhar. 2014. Media Pembelajaran. Jakarta: PT Raja Grafindo Persada.

Fadhilah, Azza Riza. 2018. "Keefektifan Model Two Stay Two Stray Berbantu Media Roda Pecahan Terhadap Kemampuan Pemecahan Masalah Matematika Kelas V SD N Kopek Godong Grobogan”. Skripsi. FIP. Pendidikan Guru Sekolah Dasar. Universitas PGRI Semarang.

Fathurrohman, Muhammad. 2017. Model-Model Pembelajaran Inovatif, Alternatif Desain Pembelajaran yang Menyenangkan.Jogjakarta: Ar-Ruzz Media.

Hamdani. 2011. StrategiBelajar Mengajar. Bandung: CV Pustaka Setia.

Hamzah, dan Muhlisrarini. 2014. Perencanaan Strategi Pembelajaran Matematika. Jakarta: Rajawali.

Heruman. 2014. Model Pembelajaran Matematika di Sekolah Dasar. Bandung: PT Remaja Rosdakarya.

Isrok'atun, dan Amelia Rosmala. 2018. Model-model Pembelajaran Matematika. Jakarta: PT Bumi Aksara.

Johnson, Trevor dan Huge Neill. 2010. Swadidik MATEMATIKA. Bandung: McGraw Hill. 
Murdiyani, Sari. 2016. "Pengaruh Model Teams Games Tournament Berbantuan Kartu Gambar Terhadap Hasil Belajar Mengidentifikasi Jenis-Jenis Tanah Siswa Kelas V SD N 01 Bakaran Wetan Juwana". Skripsi. FIP. Pendidikan Guru Sekolah Dasar. Universitas PGRI Semarang.

Rusman. 2012a. Belajar dam Pembelajaran Berbasis Komputer untuk Mengembangkan Profesionalisme Guru Abad 21. Bandung: Alfabeta

Rusman. 2012b. Model-Model Pembelajaran: Mengembangkan Profesionalisme Guru. Jakarta: Rajawali Pers

Shoimin, Aris. 2014. 68 Model Pembelajaran Inovatif Dalam Kurikulum 2013. Yogyakarta: ArRuzz Media

Sudha, I Kt., Kt. Gading, Ndara Tanggu Renda. 2016. Pengaruh Model Pembelajaran Teams Games Tournament Dan Motivasi Berprestasi Terhadap Hasil Belajar IPS Kelas IV. eJournal PGSD Universitas Pendidikan Ganesha Jurusan PGSD Vol: 4 No: 1.

Sudimahayasa, Nyoman. 2015. Penerapan Model Pembelajaran TGT Untuk Meningkatkan Hasil Belajar, Partisipasi, Dan Sikap Siswa. Jurnal Pendidikan dan Pengajaran, Jilid 48, Nomor 1-3, April 2015, hlm. 45-53.

Sudjana. 2005. Metoda Statistika. Bandung: Tarsito.

Sugiyono. 2010. Model-Model Pembelajaran Inovatif. Surakarta: Yuma Pustaka.

Sugiyono. 2017. Metode Penelitian Pendidikan (Pendekatan kuantitatif, kualitatif, dan R\&D). Bandung: Alfabeta.

Sundayana, Rostina. 2013. Media Pembelajaran Matematika. Bandung: Alfabeta.

Slavin, Robert E. 2005. Cooperative Learning : Teori, Riset dan Praktik. Bandung: Nusa Media.

Suprijono, Agus. 2017. Cooperative Learning. Yogyakarta: Pustaka Pelajar.

Purwanto. 2009. Evaluasi Hasil Belajar. Yogyakarta: Pustaka Pelajar. 